\title{
Gross and net land cover changes in the main plant functional types derived from the annual ESA CCI land cover maps (1992-2015)
}

\author{
Wei Li ${ }^{1}$, Natasha MacBean ${ }^{2}$, Philippe Ciais ${ }^{1}$, Pierre Defourny ${ }^{3}$, Céline Lamarche ${ }^{3}$, Sophie Bontemps ${ }^{3}$, \\ Richard A. Houghton ${ }^{4}$, and Shushi Peng ${ }^{5}$ \\ ${ }^{1}$ Laboratoire des Sciences du Climat et de l'Environnement, LSCE/IPSL, CEA-CNRS-UVSQ, \\ Université Paris-Saclay, 91191 Gif-sur-Yvette, France \\ ${ }^{2}$ School of Natural Resources and the Environment, The University of Arizona, Tucson, AZ 85721, USA \\ ${ }^{3}$ Earth and Life Institute, Environmental Sciences, Université catholique de Louvain, \\ Louvain-la-Neuve, Belgium \\ ${ }^{4}$ Woods Hole Research Center, Falmouth, MA, USA \\ ${ }^{5}$ Sino-French Institute for Earth System Science, College of Urban and Environmental Sciences, \\ Peking University, Beijing 100871, China
}

Correspondence: Wei Li (wei.li@ 1sce.ipsl.fr)

Received: 12 July 2017 - Discussion started: 4 August 2017

Revised: 13 December 2017 - Accepted: 23 December 2017 - Published: 30 January 2018

\begin{abstract}
Land-use and land-cover change (LULCC) impacts local energy and water balance and contributes on global scale to a net carbon emission to the atmosphere. The newly released annual ESA CCI (climate change initiative) land cover maps provide continuous land cover changes at $300 \mathrm{~m}$ resolution from 1992 to 2015, and can be used in land surface models (LSMs) to simulate LULCC effects on carbon stocks and on surface energy budgets. Here we investigate the absolute areas and gross and net changes in different plant functional types (PFTs) derived from ESA CCI products. The results are compared with other datasets. Global areas of forest, cropland and grassland PFTs from ESA are 30.4, 19.3 and 35.7 million $\mathrm{km}^{2}$ in the year 2000. The global forest area is lower than that from LUH2v2h (Hurtt et al., 2011), Hansen et al. (2013) or Houghton and Nassikas (2017) while cropland area is higher than LUH2v2h (Hurtt et al., 2011), in which cropland area is from HYDE 3.2 (Klein Goldewijk et al., 2016). Gross forest loss and gain during 1992-2015 are 1.5 and 0.9 million km² respectively, resulting in a net forest loss of 0.6 million $\mathrm{km}^{2}$, mainly occurring in South and Central America. The magnitudes of gross changes in forest, cropland and grassland PFTs in the ESA CCI are smaller than those in other datasets. The magnitude of global net cropland gain for the whole period is consistent with HYDE 3.2 (Klein Goldewijk et al., 2016), but most of the increases happened before 2004 in ESA and after 2007 in HYDE 3.2. Brazil, Bolivia and Indonesia are the countries with the largest net forest loss from 1992 to 2015, and the decreased areas are generally consistent with those from Hansen et al. (2013) based on Landsat $30 \mathrm{~m}$ resolution images. Despite discrepancies compared to other datasets, and uncertainties in converting into PFTs, the new ESA CCI products provide the first detailed long-term time series of land-cover change and can be implemented in LSMs to characterize recent carbon dynamics, and in climate models to simulate land-cover change feedbacks on climate. The annual ESA CCI land cover products can be downloaded from http://maps.elie.ucl.ac.be/CCI/viewer/download.php (Land Cover Maps - v2.0.7; see details in Sect. 5). The PFT map translation protocol and an example in 2000 can be downloaded from https://doi.org/10.5281/zenodo.834229. The annual ESA CCI PFT maps from 1992 to 2015 at $0.5^{\circ} \times 0.5^{\circ}$ resolution can also be downloaded from https://doi.org/10.5281/zenodo.1048163.
\end{abstract}




\section{Introduction}

LULCC (Land-use and land-cover change) is the essential human perturbation on natural ecosystems (Klein Goldewijk et al., 2016) and one of the main drivers of climate change (Alkama and Cescatti, 2016; Bonan, 2008) through biophysical (e.g. albedo and transpiration change; Peng et al., 2014; Zhao and Jackson, 2014) and biogeochemical effects (e.g. carbon emissions from gross deforestation and carbon sinks in secondary forest regrowth; Houghton and Nassikas, 2017). Forest loss from 2003 to 2012 was found to have caused a local increase in air temperature of about $1{ }^{\circ} \mathrm{C}$ in temperate and tropical regions, despite less solar energy being absorbed by non-forest secondary vegetation with a higher albedo (Alkama and Cescatti, 2016). Global net LULCC carbon emissions $\left(E_{\mathrm{LUC}}\right)$ are estimated to be $1.1 \pm 0.4 \mathrm{Pg} \mathrm{Cyr}^{-1}$ during the past decade (2006-2015) by the bookkeeping model of Houghton and Nassikas (2017) based on the national land cover data from the Food and Agriculture Organization of the United Nations (FAO, 2015; Keenan et al., 2015). The $E_{\mathrm{LUC}}$ diagnosed from an ensemble of land surface models (LSMs) is $1.3 \pm 0.3 \mathrm{Pg} \mathrm{Cyr}^{-1}$ during 2006-2015 (Le Quere et al., 2016) based on different (successive) versions of expanding cropland and pasture area from the HYDE dataset (Klein Goldewijk et al., 2016).

Accurate, well defined and spatially explicit gridded LULCC data are a prerequisite for calculating $E_{\mathrm{LUC}}$ in models, either under the form of annual area change in bookkeeping models or converted to changes in plant functional type (PFT) areas in LSMs. In fact, uncertain historical LULCC data are one of the largest contributors to the uncertainties in $E_{\text {LUC }}$ estimation (Bayer et al., 2017; Houghton and Nassikas, 2017). In addition to the inventory data (e.g. FAO data reported by individual countries), satellite observations in the recent three decades offer the possibility to characterize the vegetation distributions as well as their temporal changes due to both natural and anthropogenic activity. Global satellite data include the Global Land Cover 2000 (GLC2000) map based on SPOT VEGETATION (SPOT-VGT; $1 \mathrm{~km}$ resolution; Bartholomé and Belward, 2005), the MODIS Collection 5 Land Cover Product (500 m resolution; Friedl et al., 2010), forest cover maps based on Landsat (30 m resolution; Hansen et al., 2013), the GlobCover 2005 and 2009 products (300 m resolution; Bontemps et al., 2011; Defourny et al., 2012) and the European Space Agency Climate Change Initiative (ESA CCI) epoch maps based on MERIS (300 m resolution; Bontemps et al., 2013). These satellite land cover products, however, differ in terms of land cover type, spatial resolution, time span, stability and accuracy due to the different sensor designs, classification procedures and validation methods (Bontemps et al., 2012). In order to use satellite land cover (LC) products in LSMs, these maps of LC classes are usually translated into maps of PFTs to drive the carbon dynamics in vegetation and soils (Poulter et al., 2015); however, the cross-walking table between LC classes and PFTs is compli- cated by subjective decisions related to the interpretation of LC class descriptions, and therefore is a source of uncertainty in model simulations (Hartley et al., 2017). Because LC transitions of opposite directions can happen simultaneously in a $0.5^{\circ} \times 0.5^{\circ}$ grid cell, which is a typical spatial resolution of LSMs, gross transitions instead of net transitions are gradually implemented in LSMs to more accurately simulate $E_{\mathrm{LUC}}$ (Bayer et al., 2017; Shevliakova et al., 2009; Stocker et al., 2014; Wilkenskjeld et al., 2014; Yue et al., 2017). Thus, highresolution and successive long-term data on LC change are needed to generate the gross transition matrix used in LSMs. Although the products from Hansen et al. (2013) have a resolution of $30 \mathrm{~m}$, they only provide forest area change rather than changes between all LC types. Further, the gross forest gain is only available for the whole period of 2000-2012 rather than at annual time steps (Hansen et al., 2013). The previous ESA CCI epoch maps contain all LC types (Bontemps et al., 2013) but the LC transitions are not appropriate to be used in LSMs because these epoch products represent 5 -year composite maps and thus do not allow us to assess annual LC change dynamics; furthermore, only transitions to or from forest cover were considered at that time ( $\mathrm{Li}$ et al., 2016).

The newly released annual ESA CCI land cover maps from 1992 to 2015 partly overcome these challenges with $300 \mathrm{~m}$ resolution and long and successive annual time series for all major land cover transitions (i.e. the maps now include transitions between non-forest classes, including grasses, crops and urban areas; ESA, 2017) and thus can be potentially translated into PFT maps used in the LSMs. The objectives of this study are to document the major gross and net changes and transitions in PFT maps derived from annual ESA CCI LC products and to evaluate whether they can be used in LSMs. Geographical distributions and temporal trends of the translated PFT maps from ESA CCI products are characterized and compared with those from other datasets. It should be noted that our analyses are based on the PFT maps that have been translated from the ESA CCI LC maps, rather than the original LC classes, because we aim to demonstrate the differences between different datasets and provide suggestions to modellers for implementing them in LSMs.

\section{Methods}

\subsection{ESA CCI land cover products}

The annual ESA CCI LC maps cover a period of 24 years from 1992 to 2015 at a spatial resolution of $300 \mathrm{~m}$ (ESA, 2017). These maps describe the Earth's terrestrial surface in 37 original LC classes based on the United Nations Land Cover Classification System (UN-LCCS; Di Gregorio, 2005).

This unique long-term land cover time series was achieved by combining the global daily surface reflectance of five different observation systems while aiming to maintain a good 
consistency over time. This was identified as a key requirement from the modeling community (Bontemps et al., 2012). Each of these global daily measurements of multispectral radiance recorded from 1992 to 2015 have been pre-processed to complete radiometric calibration, geometric and atmospheric correction, and clouds and cloud shadow screening. The full archive of MERIS (2003-2012) providing 15 spectral bands at $300 \mathrm{~m}$ resolution was classified to establish a baseline by fusing the outputs of machine learning and unsupervised algorithms (ESA, 2017). The $1 \mathrm{~km}$ time series recorded respectively by AVHRR from 1992 to 1999, SPOTVGT from 1999 to 2013 and PROBA-V from 2014 and 2015 were used to detect and confirm the change which was eventually delineated more precisely at the $300 \mathrm{~m}$ spatial resolution whenever possible, i.e. later than 2004. This last step results in both back- and forward-dating the 10 year baseline LC map to produce the 24 annual LC maps from 1992 to 2015. In order to avoid false change detections due to the interannual variability in classifications, each change has to persist over more than 2 successive years in the classification time series to be confirmed (for more information see Sect. 3.1.2 of the ESA CCI LC Product User Guide; ESA, 2017). The resulting series of consistent $300 \mathrm{~m}$ annual LC maps from 1992 to 2015 is delivered with a pixel-based uncertainty value indicating the confidence at which a LC class was assigned for each pixel.

The accuracy of ESA CCI LC products was evaluated on a global scale according to international standards, using an independent validation dataset to produce a confusion matrix and derive overall an accuracy figure. An object-based validation database of 2600 primary sampling units was built by a panel of international experts to specifically assess the accuracy of both the LC classes and changes (ESA, 2017). Research is currently ongoing to find how to address the new challenges underlying this database, i.e. following a perobject approach and interpreting not just a unique land cover class but also a distribution of land cover classes within a primary sampling unit. The uniqueness of these two concepts in the framework of global land cover validation requires more time to derive reliable figures about LC classes and LC change accuracy. It will also prevent any comparison with previous validation figures.

In this respect, for the sake of comparison, the accuracy of the ESA CCI LC product from 2010 was assessed using the GlobCover 2009 validation database (Bontemps et al., 2011). Using all the points interpreted as "certain" by the experts, whether "homogeneous" (i.e. made of a single LC class) or "heterogeneous" (i.e. made of several or mosaic LC classes), the overall accuracy was found to be $71.5 \%$. Accounting for only the "homogeneous" and "certain" points, the overall accuracy raised to $75.4 \%$ (ESA, 2017). The highest user accuracy values were found for the classes of rainfed cropland, irrigated cropland, broadleaved evergreen forest, urban areas, bare areas, water bodies and permanent snow and ice. Conversely, mosaic classes of natural vegetation were asso- ciated with the lowest user accuracy values, as well as the three classes of lichens and mosses, sparse vegetation and flooded forest with fresh water.

The overall accuracy of the ESA CCI LC products was also assessed by independent studies over specific regions (e.g. Tsendbazar et al., 2015, over Africa and Yang et al., 2017, over China), which can give valuable insights for specific applications.

\subsection{PFT area and net changes}

The original 37 ESA CCI LC classes were first aggregated into $0.5^{\circ} \times 0.5^{\circ}$ resolution and then translated into 14 different PFTs based on the cross-walking table (Table S1 in the Supplement) from the ESA Land Cover Product User Guide (ESA, 2017). This table originated from Poulter et al. (2015) and was further adjusted for some classes due to improved understanding of how the LC class descriptions can be interpreted to estimate fractional cover of PFTs from each LC class, in particular for mosaic classes and sparsely vegetated regions. PFTs were grouped into major vegetation types: forest, shrub, grassland and cropland. The tree PFTs and shrub PFTs (Table S1) were summed to obtain the forest and shrub area respectively; thus, the shrub PFTs are excluded from tree PFTs in our analyses. The net area change was calculated by comparing two annual PFT maps at $0.5^{\circ} \times 0.5^{\circ}$ resolution.

\subsection{Gross PFT changes and transitions}

Gross changes need to be considered differently because it is only possible to derive the net change by comparing the annual $300 \mathrm{~m}$ maps sequentially. Gross changes may be far larger than the net changes, and thus may show different magnitudes or even directions of LULCC carbon fluxes when simulated in LSMs. To document all the bidirectional LC transitions at $0.5^{\circ} \times 0.5^{\circ}$ resolution, high-resolution LC transition data are needed. Therefore, the annual ESA CCI LC maps are compared year by year at $300 \mathrm{~m}$ resolution to record the gross loss and gain of each original LC class over the whole period from 1992 to 2015 . There are 23 original LC classes that experienced gross changes (classes with stars in Table S1).

In order to derive the gross transitions, all possible transitions (506 in total) between the 23 original LC classes with gross changes were calculated at $300 \mathrm{~m}$ resolution. There are a total of 422 gross transitions between these 23 original LC classes. These gross changes in the original classes were then translated into gross changes in PFTs using the LC-toPFT cross-walking table (Table S1) and grouped into the major vegetation types (forest, shrub, grassland, cropland). For example, a LC transition from class " 50 ", corresponding to $90 \%$ tree PFT in Table S1, to class " 30 " (10\% tree PFT) is taken as a forest loss of $80 \%$ in that $300 \mathrm{~m}$ grid cell. Finally, the converted transitions were aggregated into fractions in each $0.5^{\circ} \times 0.5^{\circ}$ grid cell. 
Table 1. Description and comparison of different land-use/land-cover datasets used in this study. The term of "dataset" in this study can also involve some model output (e.g. forest area from Land Use Harmonization dataset, LUH2v2h).

\begin{tabular}{|c|c|c|c|c|c|}
\hline & $\begin{array}{l}\text { PFTs from annual } \\
\text { ESA CCI maps }\end{array}$ & $\begin{array}{l}\text { LUH2v2h } \\
\text { (Hurtt et al., 2011) }\end{array}$ & $\begin{array}{l}\text { HYDE } 3.2 \\
\text { (Klein Goldewijk } \\
\text { et al., 2016) }\end{array}$ & Hansen et al. (2013) & $\begin{array}{l}\text { Houghton and Nas- } \\
\text { sikas (2017) }\end{array}$ \\
\hline $\begin{array}{l}\text { Time span } \\
\text { Time step }\end{array}$ & $\begin{array}{l}\text { 1992-2015 } \\
\text { annual }\end{array}$ & $\begin{array}{l}850-2100 \\
\text { annual }\end{array}$ & $\begin{array}{l}10000 \mathrm{BC}-2015 \\
1000 \text { year for the BCE } \\
\text { period, then } 100 \text { year } \\
\text { till } 1700,10 \text { year till } \\
2000 \text {, and from } 2000 \\
\text { to } 2015 \text { annual }\end{array}$ & $\begin{array}{l}2000-2014 \\
\text { gross loss, annual; } \\
\text { gross gain for one } \\
\text { period }(2000-2012)\end{array}$ & $\begin{array}{l}\text { 1850-2015 } \\
\text { annual }\end{array}$ \\
\hline $\begin{array}{l}\text { Spatial reso- } \\
\text { lution }\end{array}$ & $300 \mathrm{~m}$ & $0.25^{\circ}$ & $5 \operatorname{arcmin}$ & $30 \mathrm{~m}$ & country \\
\hline $\begin{array}{l}\text { Land-use/ } \\
\text { land-cover } \\
\text { type }\end{array}$ & $\begin{array}{l}\text { forest, shrub, grass- } \\
\text { land, cropland, bare } \\
\text { soil, water and urban }\end{array}$ & $\begin{array}{l}\text { forest, cropland, pas- } \\
\text { ture, rangeland, urban } \\
\text { and non-forested }\end{array}$ & $\begin{array}{l}\text { cropland, grazing } \\
\text { lands and urban }\end{array}$ & forest & forest \\
\hline Gross or net & gross and net & gross and net & net & gross and net & net at country level \\
\hline Data source & $\begin{array}{l}\text { satellite (MERIS, } \\
\text { SPOT-VGT, AVHRR, } \\
\text { and PROBA-V) }\end{array}$ & $\begin{array}{l}\text { urban, cropland, } \\
\text { pasture and rangeland } \\
\text { from HYDE } 3.2 \\
\text { (Klein Goldewijk } \\
\text { et al., 2016); forest } \\
\text { and transitions based } \\
\text { on model }\end{array}$ & $\begin{array}{l}\text { cropland and grazing } \\
\text { land are based on } \\
\text { the FAO categories } \\
\text { for "Arable land and } \\
\text { permanent crops" and } \\
\text { "Permanent meadows } \\
\text { and } \\
\text { pastures" (FAOSTAT, } \\
\text { 2015); Spatial distri- } \\
\text { bution based on ESA } \\
\text { CCI epoch LC map } \\
2010\end{array}$ & satellite (Landsat) & $\begin{array}{l}\text { FAO FRA (FAO, } \\
2015) \text { based on } \\
\text { country reports }\end{array}$ \\
\hline Advantage & $\begin{array}{l}\text { full land cover types; } \\
\text { relatively long time } \\
\text { series; relatively high } \\
\text { resolution; full gross } \\
\text { transitions }\end{array}$ & $\begin{array}{l}\text { full gross transitions; } \\
\text { long time series }\end{array}$ & $\begin{array}{l}\text { long time series; } \\
\text { inventory-based }\end{array}$ & high resolution & inventory-based \\
\hline Disadvantage & $\begin{array}{l}\text { no specific pasture; } \\
\text { uncertainty in cross- } \\
\text { walking table }\end{array}$ & $\begin{array}{l}\text { no separation of de- } \\
\text { ciduous and evergreen } \\
\text { forest; model-based } \\
\text { forest areas; model- } \\
\text { based temporal } \\
\text { changes in historical } \\
\text { cropland and grazing } \\
\text { land (HYDE 3.2) }\end{array}$ & $\begin{array}{l}\text { no forest; coarse time } \\
\text { steps }\end{array}$ & $\begin{array}{l}\text { short time period; no } \\
\text { annual forest gain, but } \\
\text { only for the whole pe- } \\
\text { riod of } 2000-2012 ; \text { no } \\
\text { other LC types }\end{array}$ & $\begin{array}{l}\text { not grid-cell explicit; } \\
\text { no other LC types; } \\
\text { inconsistency of data } \\
\text { sources and forest } \\
\text { definitions between } \\
\text { different countries }\end{array}$ \\
\hline
\end{tabular}

\subsection{Comparison with other datasets}

Three land-use and land-cover datasets (Table 1) were used for comparison: (i) forest, grassland and cropland area from the Land Use Harmonization (LUH2v2h) dataset (Hurtt et al., 2011); (ii) forest cover data from Hansen et al. (2013) and (iii) national forest area data from Houghton and Nassikas (2017). The cropland and pasture areas in the LUH2v2h dataset are from HYDE 3.2 (Klein Goldewijk et al., 2016), in which the ESA CCI epoch LC map in 2010 (representing 2008-2012) was used as a spatial reference map for the area allocation and the national cropland and grazing land were adjusted to match the FAO STAT data (FAOSTAT, 2015) as close as possible. The national forest areas from
Houghton and Nassikas (2017) are based on FAO Forest Resources Assessment (FRA) data (FAO, 2015; also see Keenan et al. ,2015, for the main findings of FAO FRA 2015). Thus, these two additional sources of data, HYDE 3.2 (Klein Goldewijk et al., 2016) and FAO FRA (FAO, 2015) were not shown in the figures.

It should be noted that land use data are not necessarily the same as land cover data, and the exact definitions and categorization of forest (cropland and grassland) are different for each dataset (see details in Discussion). Nevertheless, these represent the best datasets available for the use in LSMs for comparison, and we have tried to harmonize the definitions where possible (see below), but to some degree this is an ongoing discussion between the modeling and data commu- 
nities. Furthermore, all the LSMs have to use these datasets for deriving PFT changes back through time, so it is a very worthwhile exercise to determine if the broad groupings differ, and to what extent.

Absolute areas, net changes and gross transitions from 1992 to 2015 in the LUH2v2h dataset (Hurtt et al., 2011) were used for comparison. Forest used in this study from LUH2v2h (Hurtt et al., 2011) refers to the total of primary and secondary forest, cropland refers to all crop types and grassland refers to the total of pasture and rangeland. Because LUH2v2h data use cropland and grazing land areas from HYDE 3.2 as an input (Hurtt et al., 2011), the spatial distributions are mainly determined by HYDE 3.2. The gross transitions in LUH2v2h data are calculated from the Global Land Use Model (Hurtt et al., 2006) that tracks sub-grid cell loss and gain in land use categories. They first determined the urban area in each grid cell proportionally from cropland, pasture and secondary lands, and if these areas cannot fulfill the urban increase, primary lands were cleared. The minimum transition rates between cropland, pasture and other (sum of primary and secondary) lands were then calculated to identify the gross transitions between these land use categories (Hurtt et al., 2011). Transitions related to shifting cultivation and wood harvest were determined last (Hurtt et al., 2011).

Only annual gross forest loss each year during 2000-2014 and total gross forest gain during 2000-2012 are available in the dataset of Hansen et al. (2013). Thus, the net forest area change from this dataset only refers to the period of 20002012. The national forest area data from 1992 to 2015 in the dataset of Houghton and Nassikas (2017) were used to calculate the forest area changes.

A land mask with nine regions (Fig. 1) defined by Houghton (1999) was used to derive the regional values.

\section{Results}

\subsection{PFT areas in the year 2000}

After translating the original ESA CCI LC classes into PFTs using the cross-walking table (Table S1), the global and regional areas of forest, cropland and grassland PFTs in the year 2000 are shown in Fig. 1. Global areas of forest (excluding shrub), cropland and grassland PFTs are 30.4, 19.2 and 35.7 million $\mathrm{km}^{2}$, respectively Global forest area is 6.7 , 11.2 or 10.1 million $\mathrm{km}^{2}$ lower than that from LUH2v2h (Hurtt et al., 2011), Hansen et al. (2013) or Houghton and Nassikas (2017), respectively. It is also much lower than the recently reported global forest area of 43.3 million $\mathrm{km}^{2}$ with increased forest area estimate in dryland biomes using Google Earth images (Bastin et al., 2017). Global cropland area from ESA CCI is 4.2 million $\mathrm{km}^{2}$ larger than that from LUH2v2h, while the difference in global grassland area is relatively small.
Forest area from ESA CCI is lower than that from Hansen et al. (2013) in all regions except North Africa and Middle East and the Pacific developed region. Here, the regions refer to the defined regions in Fig. 1. Forest area from LUH2v2h (Hurtt et al., 2011) is larger than that from ESA CCI in most regions except in South and Central America, tropical African and the Pacific developed region. Forest area from Houghton and Nassikas (2017), however, is systematically higher than that from ESA CCI in all regions. Cropland area from ESA CCI matches that from LUH2v2h (Hurtt et al., 2011) in North America but is higher in all the other regions. Although the global grassland area is similar between ESA CCI and LUH2v2h (Hurtt et al., 2011), larger differences are seen on a regional scale. Grassland area from ESA CCI was found to be much higher than that from LUH2v2h (Hurtt et al., 2011) in North America and the former Soviet Union (4.0 and 3.5 million $\mathrm{km}^{2}$ higher, respectively) but much lower $\left(2.4\right.$ million $\left.\mathrm{km}^{2}\right)$ in North Africa and Middle East.

\subsection{Gross area change}

\subsubsection{Time series of gross PFT change}

After translating all of the 422 gross transitions detected between the original ESA LC classes into PFTs, the time series of gross changes in PFTs are shown in Fig. 2, and the mean annual change rates are shown in Table S2. Generally, the gross changes are related to the net, i.e. where there are more gross changes, more net changes can be found. Major gross changes occur in forest, cropland and grassland PFTs, with a global gross gain of $0.91,1.2$ and 1.1 million $\mathrm{km}^{2}$ and a global gross loss of 1.5, 0.56 and 0.98 million $\mathrm{km}^{2}$ respectively, from 1992 to 2015. The magnitudes of gross changes in these three PFTs are larger before 2005 than after 2005. Especially during the late 1990s, both intensive gross forest loss and gain occurred but overall resulted in net forest loss. Accordingly, both gross and net cropland area expands during this period. Two other peaks of net forest loss were found in 1995 and 2004, during which net cropland area increased. Although grassland experienced large gross loss and gross gain, the net area remains stable, except in 2004 where a net increase was found.

The temporal correlations of gross and net changes between ESA CCI PFTs, Hansen et al. (2013) and LUH2v2h (Hurtt et al., 2011) are not significant ( $p>0.05$, Table S3). The magnitudes of gross changes in forest from LUH2v $2 \mathrm{~h}$ (Hurtt et al., 2011) and Hansen et al. (2013) and cropland from LUH2v2h (Hurtt et al., 2011) are much larger than those detected from ESA CCI PFT maps (Fig. 2). In contrast to gross changes of forest and cropland from ESA CCI maps, annual gross changes from LUH2v2h (Hurtt et al., 2011) show larger variations after 2005 than before 2005. Especially before 2000, the annual gross changes in forest and cropland from LUH2v2h (Hurtt et al., 2011) are constant because HYDE 3.2 provides cropland and pasture 

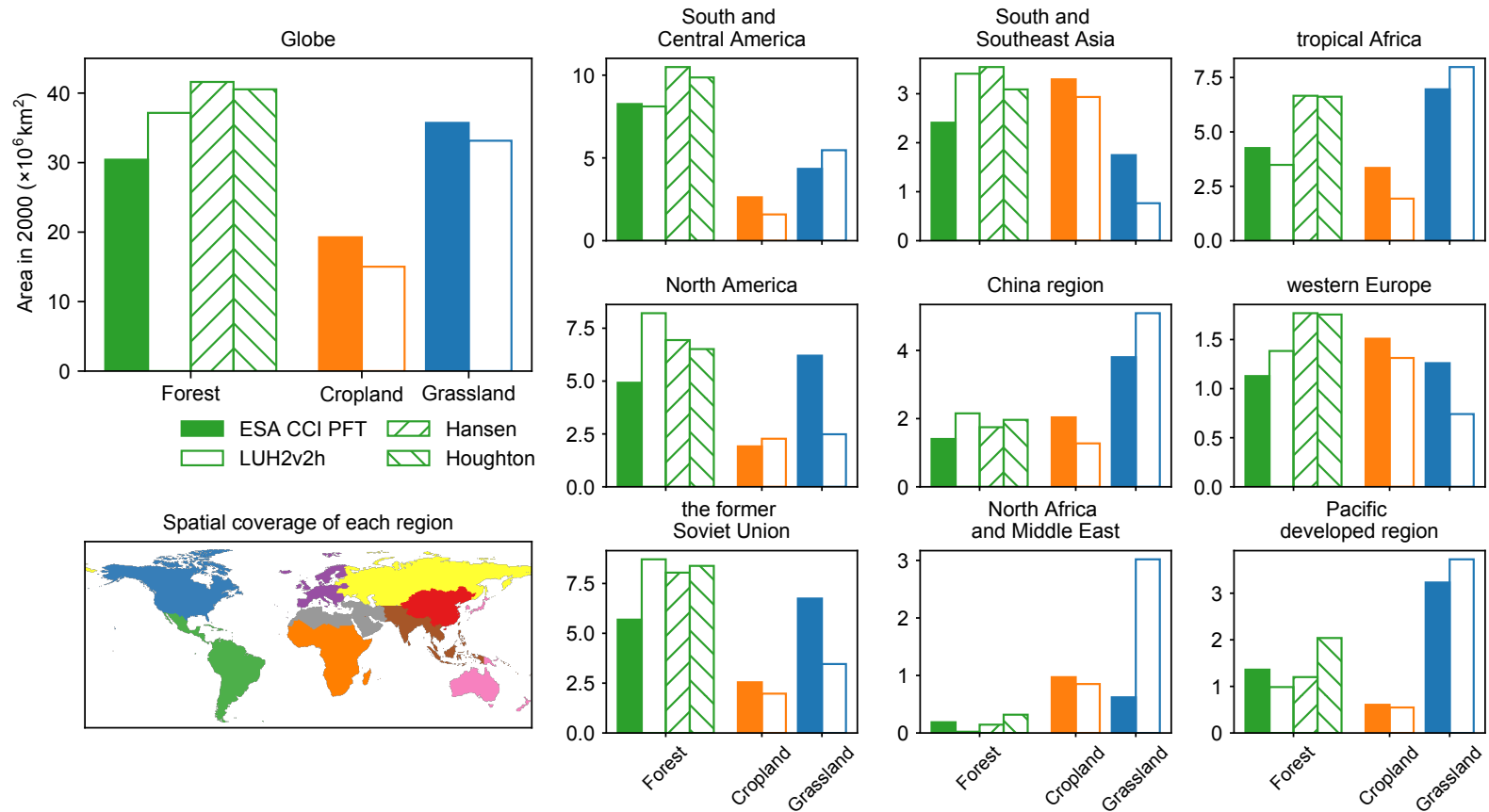

Figure 1. Global and regional areas of forest, cropland and grassland PFTs in the year 2000 in comparison with data from LUH2v2h (Hurtt et al., 2011), Hansen et al. (2013) and Houghton and Nassikas (2017). Different colours indicate different PFTs.

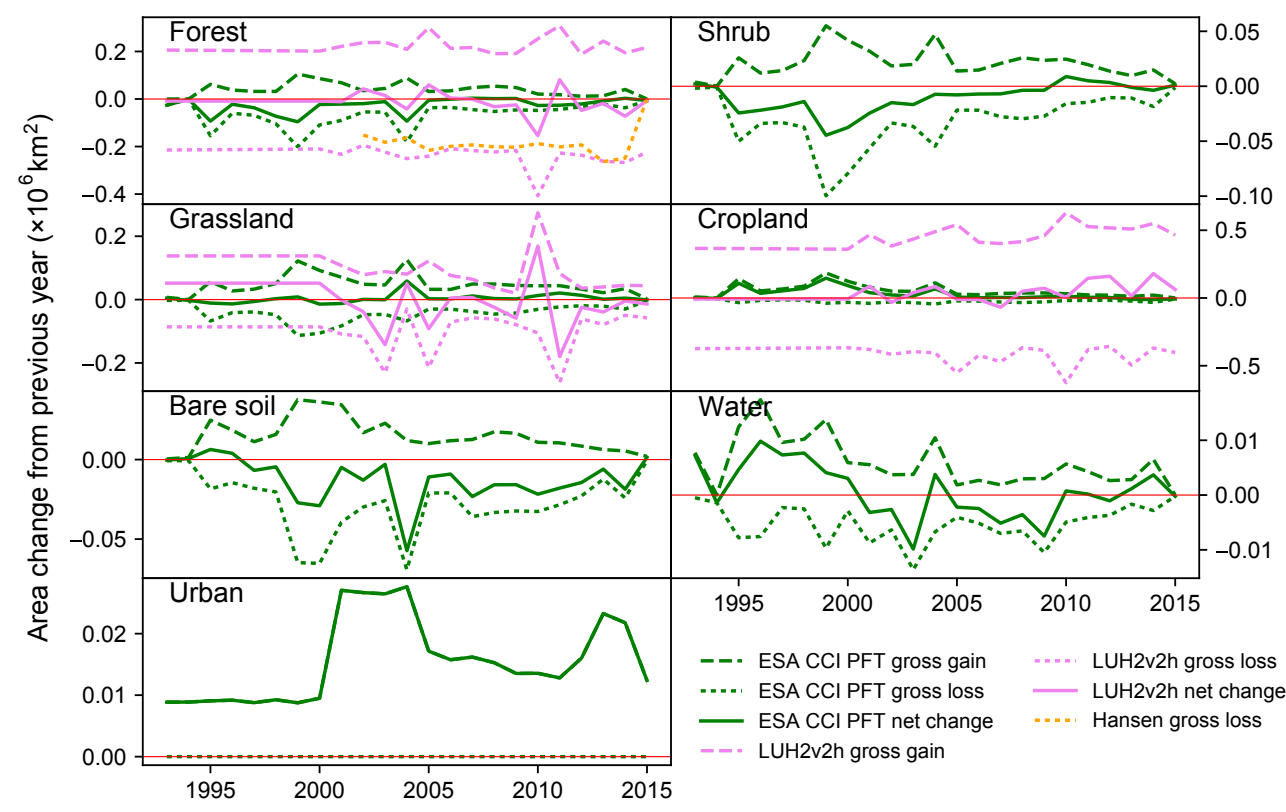

Figure 2. Gross changes in PFTs from 1992 to 2015 after translating gross transitions between original ESA land cover classes. Gross changes from LUH2v2h (Hurtt et al., 2011) and Hansen et al. (2013) are also shown for comparison. The red line indicates the zero line.

area only at a 10-year time step before 2000 (at an annual time step after 2000), and a linear interpolation was used in LUH2v2h (Hurtt et al., 2011) to produce the annual maps from HYDE 3.2 before 2000. The net forest loss and corresponding net cropland gain in 2004 coincides with the ESA CCI PFT maps and LUH2v2h (Hurtt et al., 2011) but the years of cropland gain in HYDE 3.2 are rather different from in ESA CCI PFTs during the other periods. Although the difference in the magnitude of gross grassland changes between ESA CCI PFTs and LUH2v2h (Hurtt et al., 2011) is relatively smaller than that of forest and cropland, the net grassland changes are not consistent over time. 


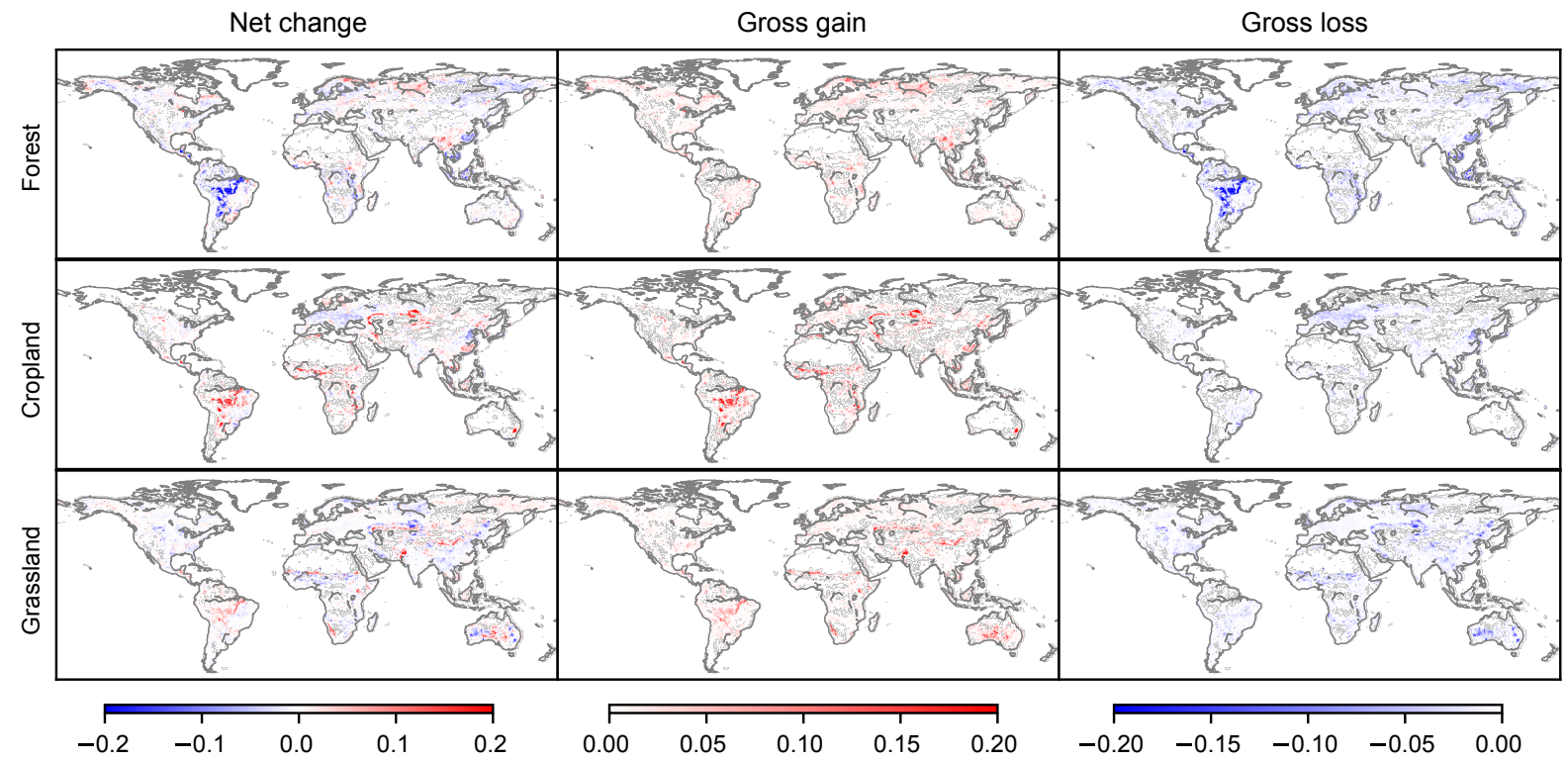

Figure 3. Spatial distributions of net and cumulative gross changes in forest, cropland and grassland PFTs between 1992 and 2015 derived from the ESA CCI data. The color scales indicate the changed fraction in each half-degree grid cell.

Gross changes in shrub and bare soil are also detected over the whole period, and the net change in these PFTs is generally a loss in area. The magnitudes of gross water body area changes are small compared to other PFTs. There is a relatively large net increase during 1995-2000 and a moderate net decrease during 2000-2010. Urban areas keep expanding over the whole period, and the increasing rates are high during 2001-2004 and 2012-2014.

\subsubsection{Spatial distributions of gross PFT changes}

The spatial distributions of net and cumulative gross changes in forest, cropland and grassland PFTs between 1992 and 2015 are shown in Fig. 3, and the distributions of the other PFTs are shown in Fig. S1. Intensive gross forest loss and sparse gross forest gain in South America result in a strong net decrease in forest area (Fig. 3). There are also considerable gross and net forest losses in South and Southeast Asia and in some regions of tropical Africa. Gross forest gain occurs pervasively in boreal regions. Some regions of intensive gross forest gain were found in south Asia, tropical Africa and South America, but with a small extent. Gross cropland gain occurs all over the world, and especially in South America, tropical Africa (particularly in the Sahel), South and Southeast Asia, and central Asia. By contrast, gross cropland loss is only observed in Europe and across the North China Plain. The cropland loss in these two regions is mainly caused by urbanization and thus an increase in urban area was found (Fig. S1). Overall, the net cropland change is an increase in most regions except Europe and the North China Plain. Grassland in temperate and tropical regions experienced extensive gross gain and gross loss, but the gross gain and loss are not fully coincident, leading to a pattern of coexisting net gain and loss everywhere (Fig. 3). The changes in grassland are relatively small in boreal regions.

The changes to shrubs are largely distributed in tropical regions, with a net gain in South America and net loss in tropical Africa and south Asia (Fig. S1). Intensive gross changes in bare soil were found in north China, central Asia, Australia and the south edge of the Sahara, mainly caused by the gross transitions between original ESA LC classes "200" (bare areas) and "150" (sparse vegetation; tree, shrub, herbaceous cover $<15 \%$ ). Water body changes are relatively small compared to other PFTs. In addition to the urban area increase over cropland in Europe and the North China Plain, there is also urban expansion to cropland in the United States (Fig. S1).

\subsection{Net area change of PFTs}

\subsubsection{Global change}

The global and regional net area changes in forest, cropland and grassland PFTs from ESA CCI LC maps since 1992 are shown in Fig. 4 (solid lines). Global net forest loss and net cropland gain between 1992 and 2015 are 0.60 and 0.67 million $\mathrm{km}^{2}$, respectively. Global forest area decreased fast from 1992 to 2004 accompanied by fast increases in cropland. Forest area stayed stable between 2004 and 2009 and then decreased again, although by a smaller magnitude than in 1992-2004, during the recent period from 2009 to 2015. Meanwhile, cropland area remains relatively stable since 2004. Net grassland changes are small compared to forest and cropland changes. 

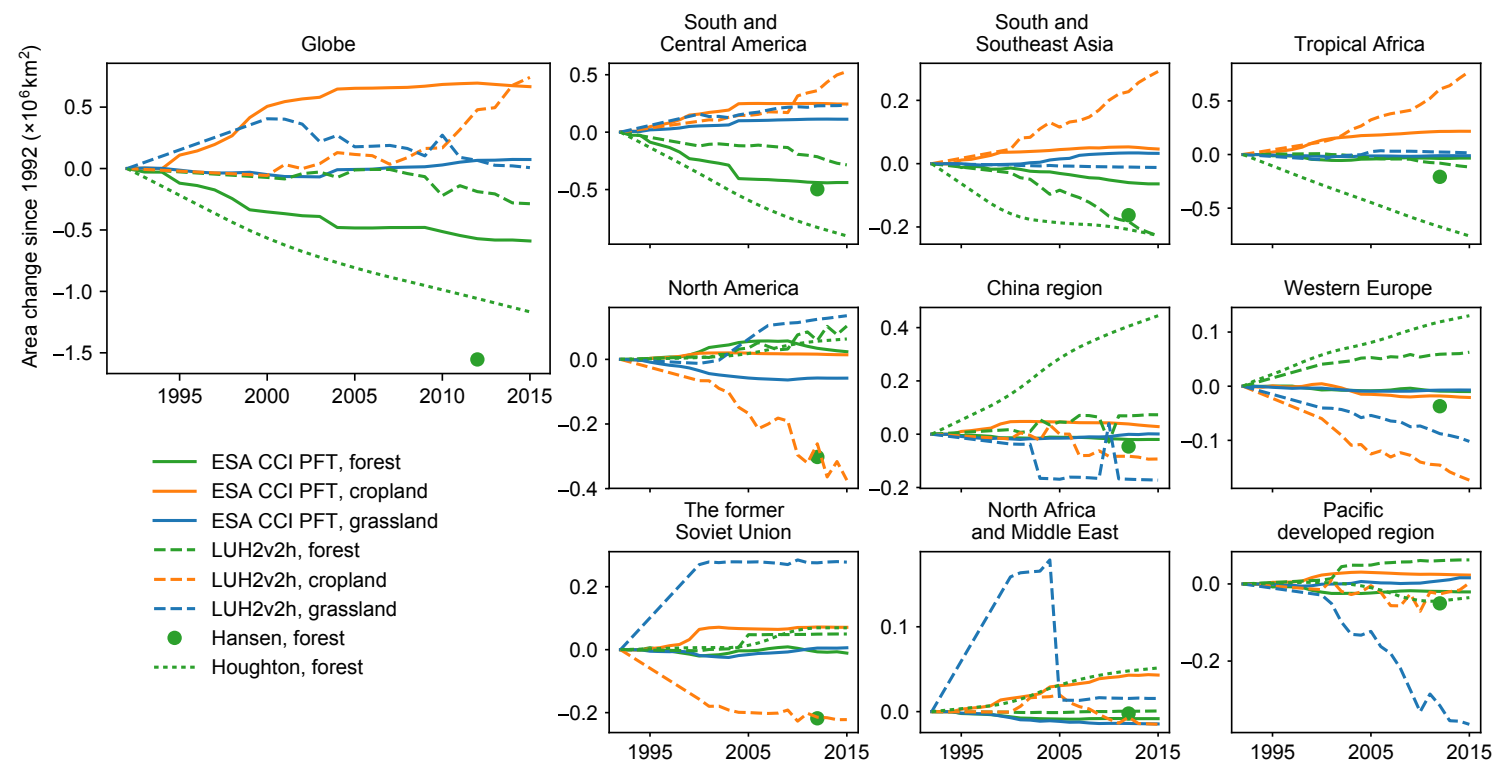

Figure 4. Global and regional net area changes in forest, cropland and grassland PFTs derived from ESA CCI land cover maps since 1992. Data from LUH2v2h (Hurtt et al., 2011), Hansen et al. (2013) and Houghton and Nassikas (2017) are also shown for comparison. Note that net forest area change from Hansen et al. (2013) is corresponding to the period of 2000-2012, and thus the forest area change between 1992 and 2000 from ESA CCI was added as Hansen et al. (2013) data in the plot.

The magnitudes of net forest area change from LUH2v2h (Hurtt et al., 2011) are much smaller than those from ESA CCI, mainly because the forest area decrease between 1992 and 2009 (Fig. 4) is not reflected in the LUH2v2h dataset (Hurtt et al., 2011). Although the net increased cropland areas from 1992 to 2015 are similar between ESA CCI and LUH2v2h (Hurtt et al., 2011), the temporal trajectories are rather different. The increase in cropland in ESA CCI data happened between 1992 and 2004, while cropland area in LUH2v2h (Hurtt et al., 2011) mainly increased since 2007 (Fig. 4). Grassland area changes in LUH2v2h (Hurtt et al., 2011) display more variations than those from ESA CCI. There was an increase in grassland in LUH2v2h (Hurtt et al., 2011) in the earlier period (1992-2004) where ESA CCI had the increase in cropland. Globally, net forest area loss between 1992 and 2015 from both Hansen et al. (2013) and Houghton and Nassikas (2017) is much larger than that from ESA CCI and LUH2v2h data (Hurtt et al., 2011).

\subsubsection{Regional change}

Consistent with the spatial distributions of net forest change in Fig. 3, net forest loss in South and Central America dominates the global net forest loss (Fig. 4), accounting for $75 \%$ of the global total. The magnitude of net forest loss is close to that observed by Hansen et al. (2013) in this region. However, the magnitudes of net forest loss from ESA CCI PFTs in other regions are generally smaller than those from Hansen et al. (2013). Net forest area change from Houghton and Nassikas (2017) also shows a stronger loss in all three tropical regions than that in other datasets, especially in South and Central America and tropical Africa. It should be noted that the net forest loss in South and Southeast Asia is consistent between LUH2v2h (Hurtt et al., 2011), Hansen et al. (2013) and Houghton and Nassikas (2017), and all these datasets have much larger net forest area loss than ESA CCI data. All datasets demonstrate net forest gain in North America, except Hansen et al. (2013) which has a strong forest loss. The forest area in LUH2v2h data (Hurtt et al., 2011) and inventory-based data from Houghton and Nassikas (2017) shows a net increase in the China region and western Europe. In contrast, forest area in the satellite-based datasets of ESA CCI PFTs and Hansen et al. (2013) is stable or slightly decreasing.

South and Central America, tropical Africa and the former Soviet Union are the regions with the largest contributions to the global total net cropland increase, representing 37, 33 and $11 \%$ of the global total. The regional patterns of temporal net cropland area change are rather different between ESA CCI PFTs and LUH2v2h (Hurtt et al., 2011) although the global net changes from 1992 to 2015 are similar. Cropland from LUH2v2h (Hurtt et al., 2011) expands more in tropical regions but decreases more in other regions than in ESA CCI PFTs (Fig. 4).

Grassland area from ESA CCI PFTs slightly increases in South and Central America and South and Southeast Asia, and slightly decreases in North America, the former Soviet Union, North Africa and Middle East. Differences in grassland change are large between ESA CCI PFTs and LUH2v2h (Hurtt et al., 2011) in all regions other than tropical regions. 

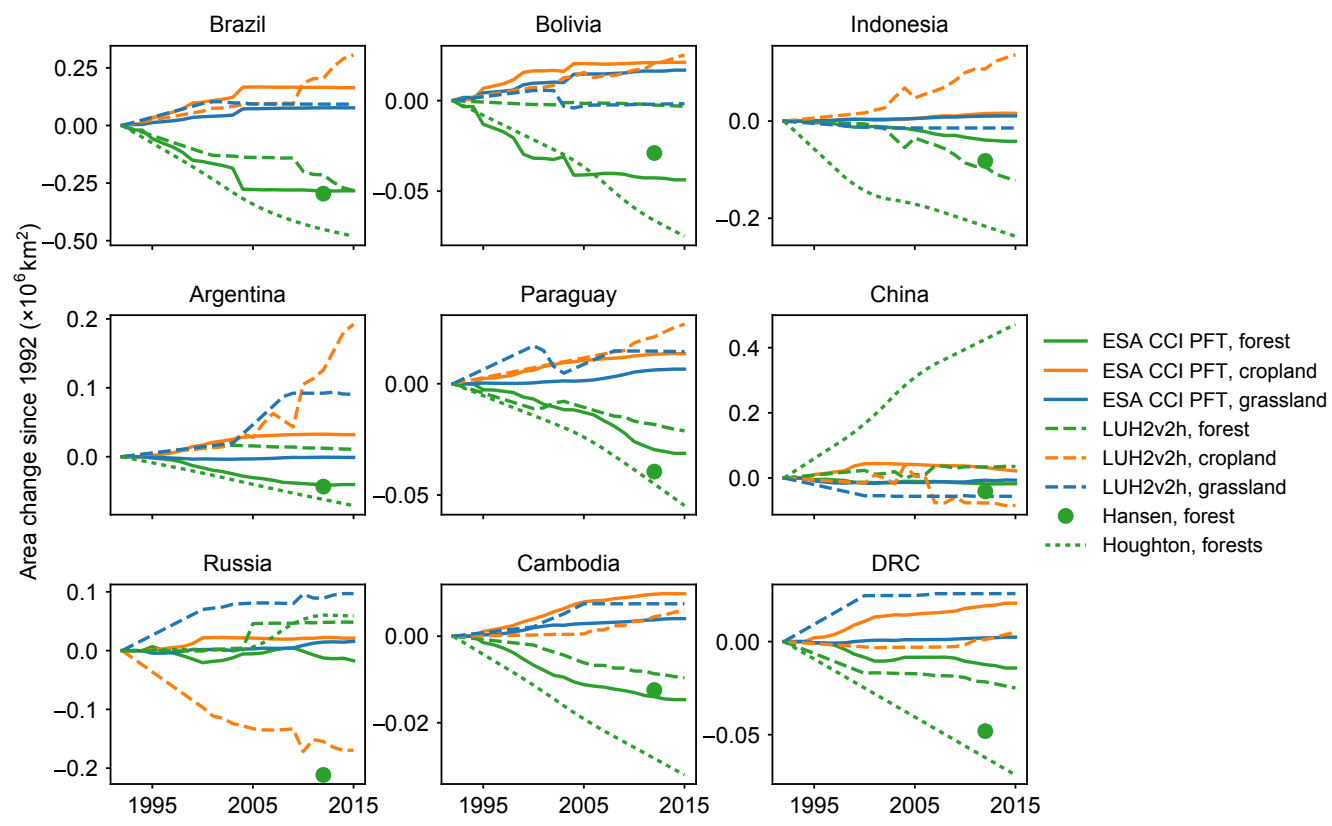

Figure 5. Net area changes in forest, cropland and grassland PFTs derived from ESA CCI land cover maps since 1992 in countries with largest net forest area loss between 1992 and 2015. Data from LUH2v2h (Hurtt et al., 2011), Hansen et al. (2013) and Houghton and Nassikas (2017) are also shown for comparison.

\subsubsection{Countries with largest net forest area loss and gain}

The countries with the largest net forest PFT area loss between 1992 and 2015 from ESA CCI maps are shown in Fig. 5, and countries with the largest net forest PFT gain in Fig. 6. Brazil, Bolivia and Indonesia are the three countries with largest net forest losses during 1992-2015 with a net loss of $0.28,0.044$ and 0.042 million $\mathrm{km}^{2}$, respectively. The net forest loss in Brazil during the whole period is consistent between ESA CCI PFTs, LUH2v2h (Hurtt et al., 2011) and Hansen et al. (2013), despite the fact that temporal patterns are different between ESA CCI and LUH2v2h (Hurtt et al., 2011). Net forest changes between ESA CCI PFTs and Hansen et al. (2013) are also similar in Indonesia, Argentina and Cambodia, while net forest loss in Russia and the Democratic Republic of the Congo (DRC) from Hansen et al. (2013) is much larger than that from ESA CCI. Net forest loss from Houghton and Nassikas (2017) is always higher than the loss from other datasets in all these countries except in China and Russia, where a net forest gain was found in Houghton and Nassikas (2017).

The overall net cropland gain from 1992 to 2015 between ESA CCI and LUH2v2h (Hurtt et al., 2011) is similar in Bolivia but is rather different in all other countries in Fig. 5. Larger cropland gain from LUH2v2h (Hurtt et al., 2011) compared to ESA CCI was found in Brazil, Indonesia, Argentina and Paraguay, while lower cropland gain was found in Cambodia and the DRC. The cropland area change in China and Russia from LUH2v2h (Hurtt et al., 2011) even shows a net loss rather than gain. Grassland area increased in Argentina, Paraguay, Russia, Cambodia and the DRC in LUH2v2h (Hurtt et al., 2011), which was not captured by ESA CCI maps.

The magnitudes of forest change in the countries with the largest forest gain in Fig. 6 are much smaller than those with largest forest loss (Fig. 5). For example, the net forest gain from 1992 to 2015 is 0.019 million km² in Canada, compared with a forest loss of 0.28 million $\mathrm{km}^{2}$ in Brazil. In these largest forest gain countries, forest area change from Hansen et al. (2013) indicates a net forest gain only in Uruguay, and a net loss or stable in other countries. Again, contrary to ESA CCI PFTs, Houghton and Nassikas (2017) forest area data show large magnitudes of net forest loss in Myanmar, North Sudan and Nigeria, and greater magnitudes of net forest gain than other datasets in Uruguay. Cropland changes from LUH2v2h (Hurtt et al., 2011) display larger magnitudes, more variations and even different directions than those from ESA CCI in these nine countries in Fig. 6. Grassland area changes from ESA CCI are rather flat, which is different from those in LUH2v2h (Hurtt et al., 2011).

\section{Discussion}

\subsection{Differences in total area of forest, cropland and grassland}

The forest, cropland and grassland areas from different datasets do not match on global or regional scales (Fig. 1), 

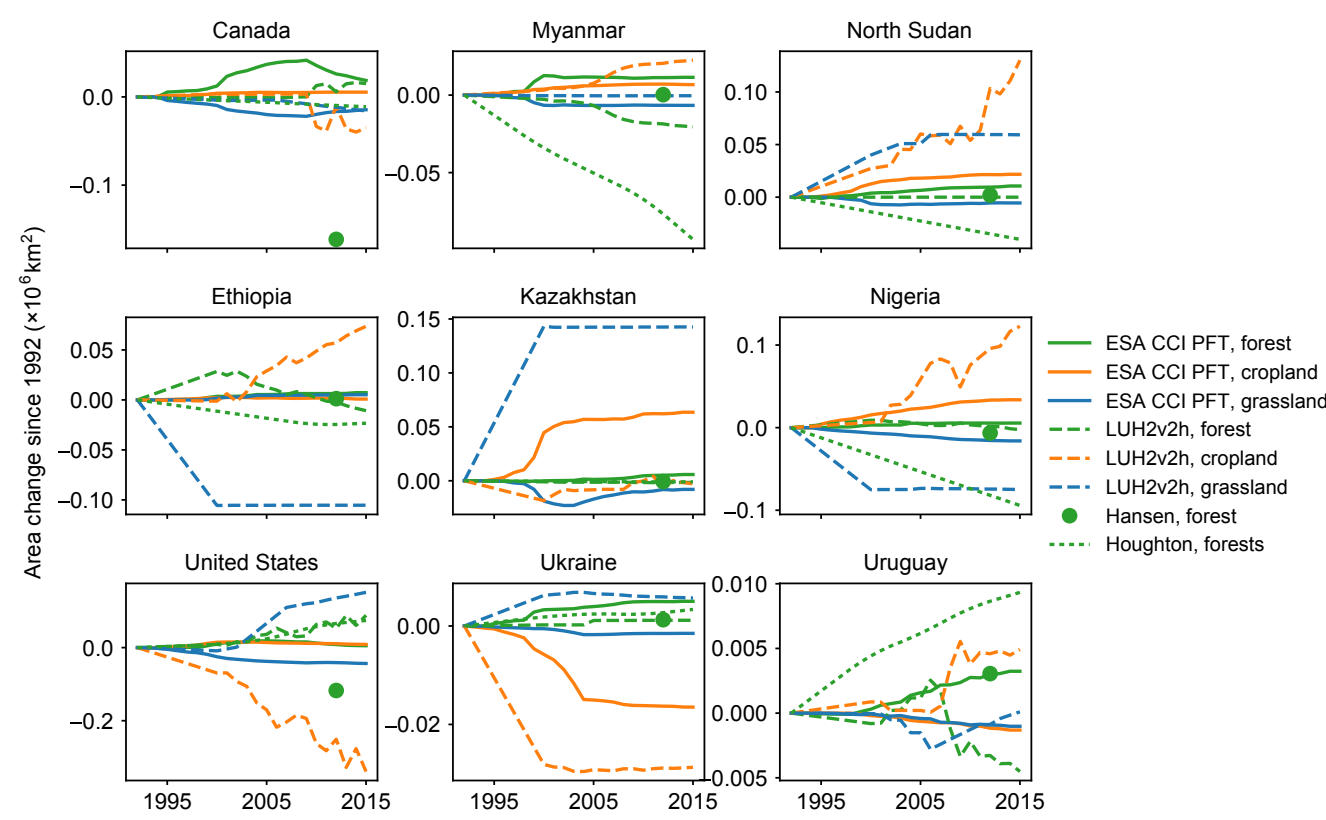

Figure 6. Net area changes in forest, cropland and grassland PFTs derived from ESA CCI land cover maps since 1992 in countries with largest net forest area gain between 1992 and 2015. Data from LUH2v2h (Hurtt et al., 2011), Hansen et al. (2013) and Houghton and Nassikas (2017) are also shown for comparison.

mainly caused by the differences in land cover definitions and data sources (Table 1), as well as the uncertainties in the cross-walking table used for translating original ESA CCI LC classes into PFTs. The canopy cover of forest varies in different ESA CCI LC classes with defined ranges such as $>$ $15 \%, 15-40 \%$ and $>40 \%$ depending on the "openness" of the canopy and according to the UN-LCCS framework provided by the FAO (Di Gregorio, 2005). Although continuous tree cover fractions are provided in data from Hansen et al. (2013), the forest cover is defined as $>25 \%$ canopy closure for trees higher than $5 \mathrm{~m}$ (Hansen et al., 2010). Forest areas in Hansen et al. (2013) are obtained from NASA's Landsat instruments with a spatial resolution of $30 \mathrm{~m}$ that can capture the small-scale forest areas. This partly explains the larger forest extent in Hansen et al. (2013) than ESA CCI PFT maps. The definition of forest by FAO, which is the data source of Houghton and Nassikas (2017), is a canopy cover $>10 \%$. FAO's forest areas are based on reports from the member countries (FAO, 2015) and the methods of compiling data in each country may vary largely, e.g. from field survey or from satellite-imagery-based estimation (Grainger, 2008; Harris et al., 2012). Furthermore, in the definition of forest by FAO, natural disturbance suppressing forests do not change the land remaining a forest, but from satellite, they are not detected as forest cover. Keenan et al. (2015) also compared the forest area from FAO FRA 2015 with remote sensing data and attributed their differences to five factors, the major one of which is the different definitions of "forest". It seems that forest area from ESA CCI PFTs is lower than that from Hansen et al. (2013) in humid regions (Fig. S2). Additionally, in the drylands like tropical Africa, it is difficult to map and estimate forest area using medium- (e.g. Landsat; Hansen et al., 2013) or coarse-resolution satellite data (e.g. ESA CCI LC; Achard et al., 2014; Bastin et al., 2017; Gross et al., 2017), in particular when tree cover is below $30 \%$ (Achard et al., 2014). Bastin et al. (2017) recently reported a forest estimate in drylands using very high spatial resolution satellite imagery, which is $40-47 \%$ more than previous forest assessments. The difficulty of detecting forest in these sparse tree cover regions could partly be responsible for the lower forest area from ESA CCI PFT maps than those from Hansen et al. (2013) and Houghton and Nassikas (2017) in tropical Africa (Fig. 1).

Forest area estimates in LUH2v2h (Hurtt et al., 2011) are based on aboveground biomass density from the Miami-LU ecosystem model (Hurtt et al., 2006), and cropland and pasture areas are based on HYDE 3.2 (Klein Goldewijk et al., 2016). HYDE 3.2 uses the cropland and pasture areas from FAO STAT (FAOSTAT, 2015) as the main land-use input data and the ESA CCI epoch LC map of 2010 as a spatial reference map (Klein Goldewijk et al., 2016). Thus, the grasslands in LUH2v2h refer to the sum of intensively managed pastures and less intensively used rangelands (Klein Goldewijk et al., 2016), while the grassland PFT from ESA CCI maps also includes natural grassland, which may be the reasons for less grassland in LUH2v2h (Hurtt et al., 2011) than ESA CCI, especially in the former Soviet Union, western Europe and North America (Fig. 1). 
Similarly, the underestimate in cropland area in ESA CCI maps (Fig. 1) is likely due to differences in definitions of what constitutes a cropland based on remote sensing datasets used to derive the ESA maps vs. land use statistics and country-dependent reporting used to derive FAO statistics that are used to define croplands in HYDE 3.2 (Klein Goldewijk et al., 2016), in addition to differences in spatial resolution. For example, the attribution of oil palm plantations is an important factor for the differences in area changes between different datasets, especially in Indonesia. Oil palm is taken as cropland rather than forest in the FAO definitions (FAOSTAT, 2015) but detected as tree covers from the remote sensing (Carlson et al., 2012, 2013; Hansen et al., 2013; Koh et al., 2011; Tropek et al., 2014), including in the CCI LC products. This partly explains that the larger cropland increase in LUH2v2h (Hurtt et al., 2011) and larger forest decrease in Houghton and Nassikas (2017) than those in ESA CCI PFTs and Hansen et al. (2013) in Indonesia (Fig. 4). Furthermore, the classification of cropland in ESA CCI is also based on remote sensing temporal analysis. In the ESA CCI algorithm, for example, spectral features at key moments during the year were used to optimize the discriminations between all major crop classes: differentiating between cropland and natural vegetation (typically harvesting dates). Cropland in LUH2v2h that is essentially from FAO statistics (Klein Goldewijk et al., 2016), on the other hand, depends on country reporting and therefore comprises different definitions and data sources.

Pérez-Hoyos et al. (2017) provide an extensive comparison of multiple cropland datasets, including ESA CCI epoch and annual maps, for the purposes of cropland monitoring, and they found that the ESA CCI 2015 annual map is more suitable for cropland monitoring than the epoch map because of the reduction in cropland area over the Congo basin. They also showed that spatial resolution is a key driver of product suitability for agriculture monitoring (Pérez-Hoyos et al., 2017). However, the specific framework of their study is the suitability for agriculture monitoring for early warning and they focus on a limited number of countries selected to be "with high risk of food insecurity" (Pérez-Hoyos et al., 2017). The issues of cropland area from the ESA CCI LC maps discussed in their study is fully justified for a study addressing the challenge of cropland monitoring, but it does not allow generalizing the conclusion to all domains (e.g. to derive PFT maps for use in global land surface modeling in this study). As Pérez-Hoyos et al. (2017) and our study show, the agreement (or lack thereof) is country-dependent, further implying that more consistent definitions of LC classes are required and/or regional LC satellite mapping algorithms (or cross-walking table, see below) are needed. Cropland mapping issues, including those discussed in Pérez-Hoyos et al. (2017) are being addressed in upcoming versions of the ESA CCI maps. Additionally, Waldner et al. (2016) have produced a product that aims to combine the "fittest" LC maps on the country level into a unified $250 \mathrm{~m}$ resolution cropland product, but again this is dependent upon a specific definition (the JECAM, Joint Experiment of Crop Assessment and Monitoring, cropland definition for the purposes of cropland monitoring).

The final spatial area of each PFT in this study is derived from a combination of the ESA LC map and the crosswalking table (Table S1) used for translating original ESA LC classes into PFTs. The range in tree cover canopy openness (as discussed above) and percent of each type of vegetation for mosaic LC classes in the LC description contributes to uncertainty in the conversion fractions used to translate the LC classes into PFTs in the cross-walking table. Thus, uncertainties in the cross-walking table contribute to the differences in forest, cropland and grassland PFT areas when comparing with other datasets. Only one value is used to prescribe the fraction of each PFT for a given class, e.g. class " 50 " corresponds to $90 \%$ of broadleaf evergreen trees in Table S1. This hinders an explicit representation of spatially heterogeneous tree cover fractions. In the absence of other information, the approximate mid-point of the range in the LC class description is used when calculating the fraction of forest PFT from a given LC class. For example, class "61" represents a closed canopy (> 40\%) and therefore we use a LC-to-tree PFT conversion fraction of $70 \%(0.7)$ as the mid-point between 40 and $100 \%$ (Table S1). Class "62", on the other hand, is an open canopy (15-40\% cover) and therefore we use a LC-to-tree PFT conversion factor of $30 \%$. Some exceptions to this general rule are made when we have a better understanding of the species or biomes included in a given LC class. For example, class " 50 " (broadleaved evergreen trees) encompasses tropical rainforests. Although the class description states that the canopies in this class can be closed to open ( $>15 \%$ ), we know that the tree cover fraction is much higher than a mid-point of $\sim 60 \%$, therefore we use a conversion factor of $90 \%$. However, this level of knowledge is not available for all LC classes. This is particularly true for mosaic and sparse vegetation classes (e.g. classes "100", "110" and "150") that span different regions/biomes that may contain different fractional coverages of vegetation.

Likewise, an explicit regional classification is required for cropland. For example, class "10" (cropland, rainfed) is separated well in North America, i.e. mainly partitioning into class " 11 " (herbaceous cover), and thus the cropland area in this region is highly consistent with LUH2v2h data (Hurtt et al., 2011; Fig. 1). In tropical Africa where class "10" is not separated into a more detailed classification, the difference in cropland areas between these two datasets are large (Fig. 1). This is because if most of the cropland in this region belongs to class " 12 ", using the corresponding value for class " 10 " in the cross-walking table ( $90 \%$ for class " 10 " vs. $30 \%$ for class "12", Table S1) overestimates cropland areas.

Hartley et al. (2017) also investigated the uncertainty in simulations of carbon, water and energy fluxes from three LSMs as a result of cross-walking table uncertainty. This study found that the spread in model outputs due to cross- 
walking uncertainty was higher than uncertainty due to the underlying LC maps (mapping algorithm; Hartley et al., 2017). Despite these uncertainties, satellites provide the only plausible way to derive the global maps of vegetation distribution needed to drive LSMs and validate dynamic global vegetation models. Future efforts by the ESA CCI LC project and collaborators will focus on reducing the uncertainty introduced when translating from LC to PFT, including using optimized and regionally based cross-walking tables.

\subsection{Differences in area changes}

The ESA CCI LC magnitudes of gross changes for all PFTs are lower than those of all three products considered. This is explained by the effect of spatial resolution combined with a change consolidation approach. Using Earth observation time series of $1 \mathrm{~km}$ spatial resolution to annually detect the land cover change for the ESA CCI maps does not allow capturing small-scale LC changes, which is part of the reason for smaller gross and net forest changes than those in Hansen et al. (2013). On the other hand, this is the only way to have a consistent method of LC change detection over the whole period. In spite of the consolidation strategy, confirming the change over several years, ESA CCI LC trends of area change mitigate only partly the impact of the heterogeneous quality of the data acquired by the various sensors. For instance, larger change variations for forest and cropland in the 1990s result from poorer radiometric and spectral quality of the AVHRR input data. This instrument, first designed for meteorological observation, is, however, the only one recording the land surface systematically before 1999 .

The large magnitude of gross changes in forest and cropland in LUH2v2h (Hurtt et al., 2011; Fig. 2) mostly distributes in the tropical regions (Figs. S3 and S4) where gross changes reflect shifting agriculture (Heinimann et al., 2017). The gross gain and loss of forest (or cropland) in the tropics from LUH2v2h maintains a similar constant rate with other small variations (Figs. S3 and S4). This is because the gross changes in LUH2v2h are mainly generated from the shifting cultivation in the tropics by assuming a turnover rate of $6.7 \%$ year $^{-1}$ (i.e. a residence time of 15 year) of all agricultural lands (Hurtt et al., 2011) and based on a spatial distribution map from Butler (1980). The Butler (1980) map is a hand-drawn map indicating the presence or absence (no precise area or fraction) of both shifting cultivation and other non-shifting farming systems based on some regional studies and "general knowledge" (Heinimann et al., 2017). The estimate of shifting cultivation extent from LUHv2h (Hurtt et al., 2011) is thus highly uncertain because of the simple assumptions and the old reference map (representing 1960s1970s) but strongly affects the gross land use change areas. Heinimann et al. (2017) recently estimated the global extent of shifting cultivation visually using Landsat $30 \mathrm{~m}$ forest data and very-high-resolution satellite imagery from Bing and Google. They found that shifting cultivation area de- creases over the last 40 to 50 years, in particular in Southeast Asia (Heinimann et al., 2017). This, however, is not reflected in the LUH2v2h dataset (Figs. S3 and S4). From LUH1 to LUH2v2h, The area of shifting agriculture is reduced (see an example in tropical Africa; Fig. S5) because of the separation of forest from natural vegetation in LUH2 (Hurtt et al., 2011). However, the gross forest changes in LUH2v2h (Hurtt et al., 2011) are still much higher than those in ESA CCI PFTs and Hansen et al. (2013). Especially in the ESA $300 \mathrm{~m}$ resolution data, the gross change area seems very small (Figs. S3 to S5). Therefore, the shifting cultivation area in LUH2v2h may be overestimated due to (1) the binary (presence/absence) indication rather than a precise extent of shifting cultivation in the Butler (1980) map and (2) no temporal change (missing the decreasing trend) of the reference map. Still, it should be noted that the coarse spatial resolution of ESA CCI products cannot detect small-scale LC changes, resulting in an underestimation of gross changes. The shifting cultivation today remains extensive and is very important for land carbon modeling, but there are only very limited studies on the regional or national extent estimates (Heinimann et al., 2017). More research and developments in the mapping and change detection of shifting cultivation are urgently desired.

The discrepancies in temporal PFT net area changes between ESA CCI maps and FAO data (cropland and pasture area changes in LUH2v2h, Hurtt et al., 2011, and forest area changes in Houghton and Nassikas, 2017; Figs. 46) are mainly caused by the different approaches for estimating LC change used by different countries in FAO reports (FAO, 2015; FAOSTAT, 2015). Some countries like Canada distinguish land use and land cover when compiling forest statistics. For example, a forest cleared for wood harvest is not taken as a forest loss because new secondary forest will be planted on this land, thus no change in land use (Keenan et al., 2015). However, remote sensing can easily detect such land cover change and treat it as forest loss. Cropland and pasture in HYDE 3.2 (Klein Goldewijk et al., 2016) adopted the FAO categories for "Arable land and permanent crops" and "Permanent meadows and pastures", respectively, as the main data source. In the ESA CCI LC maps, pastures are mapped as grassland and translated into $100 \%$ "Natural Grass" PFT (Table S1). The different trajectories of temporal cropland changes between ESA CCI and LUH2v2h (the former shows increasing from 1992 to 2004 while the latter increases after 2007; Fig. 4) are probably caused by the time lag between the real changes and country reporting to FAO. Finally, the trends of cropland area change from FAO STAT data may contradict those from national statistics (Li et al., 2016), e.g. comparing FAO STAT data (FAOSTAT, 2015) with USDA estimates (Nickerson et al., 2011) for the United States or with NBSC estimates (NBSC, 2015) for China.

There are also many other land cover and land use datasets that can be used for comparisons to assess the accuracy of land cover or land cover change in ESA CCI LC prod- 
ucts. However, they are either regional maps (e.g. the maps for Europe from Fuchs et al., 2015) or global epoch maps (e.g. the GlobeLand30 maps for 2000 and 2010; Chen et al., 2014) and not suitable for the application in LSMs. Thus, we did not include them in this study. In fact, there have already been studies on the detailed comparisons of different datasets in a region (e.g. Fuchs et al., 2015, for Europe; Yang et al., 2017, for China; and Achard et al., 2014, for the tropics). In addition to the accuracy assessments conducted in the ESA CCI project (ESA, 2017), a systematic comparison with all other land cover datasets in future will help to validate the land cover classification and land cover change detection in the ESA CCI LC products. Instead of using a single dataset, combining a sample of several datasets is reported to be considerably more efficient and accurate to estimate land cover area and change (Olofsson et al., 2014; Sannier et al., 2016) and has been adopted as technical guidelines (GOFC-GOLD, 2016; GFOI, 2016) in the remote sensing community, especially for forest monitoring to reduce emissions from deforestation and forest degradation in developing countries (the REDD+ programme).

\section{Data availability}

The ESA CCI LC maps can be viewed online using http:// maps.elie.ucl.ac.be/CCI/viewer/index.ph, and the data products can be download from http://maps.elie.ucl.ac.be/CCI/ viewer/download.php. After entering some basic information, the land cover maps with a specific version number are available for download in the Climate Research Data Package (CRDP) section. In this study, we used the version "Land Cover Maps - v2.0.7". A protocol for translating the original ESA CCI LC maps into PFT maps and an example of a LC map and PFT map in 2000 used in this study can be downloaded from https://doi.org/10.5281/zenodo.834229 (Li et al., 2017a). The annual ESA CCI PFT maps from 1992 to 2015 at $0.5^{\circ} \times 0.5^{\circ}$ resolution can also be downloaded from https://doi.org/10.5281/zenodo.1048163 (Li et al., 2017b).

\section{Conclusions}

In this study, we compare the absolute areas and areal changes between PFTs from annual ESA CCI LC products and other datasets. In the intensive LULCC regions like South and Central America, both forest area and net forest change are consistent with those from other datasets. The detection of LC changes has significantly improved from the last version of 5-year epoch ESA CCI maps (Li et al., 2016). The detailed annual cropland changes from 1992 to 2000 fill the gaps of HYDE 3.2 data for this period, in which only decadal changes are available (Klein Goldewijk et al., 2016).

Considering the discrepancies, advantages and disadvantages among different datasets (Table 1), we propose different choices of these datasets for application in LSMs de- pending on research purposes. For example, if we would like all LSMs to share the same historical and future maps in a model intercomparison project (e.g. using LUH2v2h data in CMIP6), annual ESA CCI data products should be cautiously harmonized considering the large differences between ESA CCI and LUH2v2h (Hurtt et al., 2011). On the other hand, if we want to analyse recent carbon and water budgets with LSMs, ESA CCI maps are definitely an appropriate choice. The detailed LC classes in ESA CCI products provide a valuable reference map for modellers to partition land covers into PFTs, e.g. separating the generic forest in LUH2v2h dataset (Hurtt et al., 2011) into different forest PFTs (Table S1). LSMs can also benefit from the $300 \mathrm{~m}$ spatial resolution changes in ESA CCI products when accounting for gross land use changes to simulate the LULCC carbon fluxes. Therefore, the current annual ESA CCI land cover maps with full land cover classes, $300 \mathrm{~m}$ spatial resolution and relatively long-term time series are sufficient to be implemented in LSMs and help better characterize the recent global and regional carbon cycles.

Supplement. The supplement related to this article is available online at: https://doi.org/10.5194/essd-10-219-2018-supplement.

Competing interests. The authors declare that they have no conflict of interest.

Acknowledgements. Wei Li was supported by the EuropeanCommission-funded project LUC4C (grant no. 603542). Wei Li and Philippe Ciais were supported by the European Research Council through Synergy grant ERC-2013-SyG-610028 "IMBALANCEP". Natasha MacBean, Sophie Bontemps, Céline Lamarche and Pierre Defourny were supported by the Climate Change Initiative program supported by the European Space Agency.

Edited by: David Carlson

Reviewed by: two anonymous referees

\section{References}

Achard, F., Beuchle, R., Mayaux, P., Stibig, H.-J., Bodart, C., Brink, A., Carboni, S., Desclée, B., Donnay, F., Eva, H. D., Lupi, A., Raši, R., Seliger, R., and Simonetti, D.: Determination of tropical deforestation rates and related carbon losses from 1990 to 2010, Glob. Change Biol., 20, 2540-2554, https://doi.org/10.1111/gcb.12605, 2014.

Alkama, R. and Cescatti, A.: Biophysical climate impacts of recent changes in global forest cover, Science, 351, 600-604, https://doi.org/10.1126/science.aac8083, 2016.

Bartholomé, E. and Belward, A. S.: GLC2000: a new approach to global land cover mapping from Earth observation data, Int. J. Remote Sens., 26, 1959-1977, https://doi.org/10.1080/01431160412331291297, 2005. 
Bastin, J.-F., Berrahmouni, N., Grainger, A., Maniatis, D., Mollicone, D., Moore, R., Patriarca, C., Picard, N., Sparrow, B., Abraham, E. M., Aloui, K., Atesoglu, A., Attore, F., Bassüllü, Ç., Bey, A., Garzuglia, M., García-Montero, L. G., Groot, N., Guerin, G., Laestadius, L., Lowe, A. J., Mamane, B., Marchi, G., Patterson, P., Rezende, M., Ricci, S., Salcedo, I., Diaz, A. S.-P., Stolle, F., Surappaeva, V., and Castro, R.: The extent of forest in dryland biomes, Science, 356, 635-638, https://doi.org/10.1126/science.aam6527, 2017.

Bayer, A. D., Lindeskog, M., Pugh, T. A. M., Anthoni, P. M., Fuchs, R., and Arneth, A.: Uncertainties in the land-use flux resulting from land-use change reconstructions and gross land transitions, Earth Syst. Dynam., 8, 91-111, https://doi.org/10.5194/esd-891-2017, 2017.

Bonan, G. B.: Forests and climate change: forcings, feedbacks, and the climate benefits of forests., Science, 320, 1444-1449, https://doi.org/10.1126/science.1155121, 2008.

Bontemps, S., Defourny, P., van Bogaert, E., Kalogirou, V., and Arino, O.: GlobCover 2009: Products description and validation report, available at: http://due.esrin.esa.int/files/ GLOBCOVER2009_Validation_Report_2.2.pdf (last access: 10 November 2017), 2011.

Bontemps, S., Herold, M., Kooistra, L., van Groenestijn, A., Hartley, A., Arino, O., Moreau, I., and Defourny, P.: Revisiting land cover observation to address the needs of the climate modeling community, Biogeosciences, 9, 2145-2157, https://doi.org/10.5194/bg-9-2145-2012, 2012.

Bontemps, S., Defourny, P., Radoux, J., Van Bogaert, E., Lamarche, C., Achard, F., Mayaux, P., Boettcher, M., Brockmann, C., and Kirches, G.: Consistent global land cover maps for climate modelling communities: current achievements of the ESA's land cover CCI, in: Proceedings of the ESA Living Planet Symposium, 9-13 September 2013, Edimburgh, UK, 913, 2013.

Butler, J. H.: Economic Geography: Spatial and Environmental Aspects of Economic Activity, John Wiley \& Sons., New York, USA, 1980.

Carlson, K. M., Curran, L. M., Asner, G. P., Pittman, A. M., Trigg, S. N., and Adeney, J. M.: Carbon emissions from forest conversion by Kalimantan oil palm plantations, Nat. Clim. Change, 3, 283-287, https://doi.org/10.1038/Nclimate1702, 2013.

Carlson, K. M., Curran, L. M., Ratnasari, D., Pittman, A. M., Soares-Filho, B. S., Asner, G. P., Trigg, S. N., Gaveau, D. A., Lawrence, D., and Rodrigues, H. O.: Committed carbon emissions, deforestation, and community land conversion from oil palm plantation expansion in West Kalimantan, Indonesia, P. Natl. Acad. Sci. USA, 109, 7559-7564, https://doi.org/10.1073/pnas.1200452109, 2012.

Chen, J., Ban, Y., and Li, S.: China: open access to Earth land-cover map, Nature, 514, 434-434, https://doi.org/10.1038/514434c, 2014.

Defourny, P., Mayaux, P., Herold, M., and Bontemps, S.: Global land-cover map validation experiences: toward the characterization of quantitative uncertainty, in: Remote Sensing of Land Use and Land Cover: Principles and Applications, 207-223, CRC Press, Boca Raton, FL, USA, 2012.
Di Gregorio, A.: Land Cover Classification System: Classification Concepts And User Manual: LCCS, Food \& Agriculture Org., Rome, Italy, 2005.

ESA: Land Cover CCI Product User Guide Version 2.0, available at: http://maps.elie.ucl.ac.be/CCI/viewer/download/ ESACCI-LC-Ph2-PUGv2_2.0.pdf, last access: 10 November 2017.

FAO: Global Forest Resources Assessment 2015, Desk Reference, Rome, available at: http://www.fao.org/3/a-i4808e.pdf (last access: 10 November 2017), 2015.

FAOSTAT: Food and agriculture data, Food Agric. Organ. United Nations, available at: http://www.fao.org/faostat/en/TT1 textbackslash\#home (last access: 19 May 2017), 2015.

Friedl, M. A., Sulla-Menashe, D., Tan, B., Schneider, A., Ramankutty, N., Sibley, A., and Huang, X.: MODIS Collection 5 global land cover: algorithm refinements and characterization of new datasets, Remote Sens. Environ., 114, 168-182, https://doi.org/10.1016/j.rse.2009.08.016, 2010.

Fuchs, R., Herold, M., Verburg, P. H., Clevers, J. G. P. W., and Eberle, J.: Gross changes in reconstructions of historic land cover/use for Europe between 1900 and 2010, Glob. Change Biol., 21, 299-313, https://doi.org/10.1111/gcb.12714, 2015.

GFOI: Integration of remote-sensing and ground-based observations for estimation of emissions and removals of greenhouse gases in forests: Methods and Guidance from the Global Forest Observations Initiative, Edition 2.0, Food and Agriculture Organization, Rome, Italy, 2016.

GOFC-GOLD: A sourcebook of methods and procedures for monitoring and reporting anthropogenic greenhouse gas emissions and removals associated with deforestation, gains and losses of carbon stocks in forests remaining forests, and forestation. GOFC-GOLD Report version COP22-1, GOFC-GOLD Land Cover Project Office, Wageningen University, the Netherlands, 2016.

Grainger, A.: Difficulties in tracking the long-term global trend in tropical forest area, P. Natl. Acad. Sci. USA, 105, 818-823, https://doi.org/10.1073/pnas.0703015105, 2008.

Gross, D., Achard, F., Dubois, G., Brink, A., and Prins, H. H. T.: Uncertainties in tree cover maps of Sub-Saharan Africa and their implications for measuring progress towards CBD Aichi Targets, Remote Sens. Ecol. Conserv., online first, https://doi.org/10.1002/rse2.52, 2017.

Hansen, M. C., Stehman, S. V. and Potapov, P. V.: Quantification of global gross forest cover loss, P. Natl. Acad. Sci. USA, 107, 8650-8655, https://doi.org/10.1073/pnas.0912668107, 2010.

Hansen, M. C., Potapov, P. V., Moore, R., Hancher, M., Turubanova, S. A., Tyukavina, A., Thau, D., Stehman, S. V, Goetz, S. J., Loveland, T. R., Kommareddy, A., Egorov, A., Chini, L., Justice, C. O., and Townshend, J. R. G.: Highresolution global maps of 21 st-century forest cover change., Science, 342, 850-853, https://doi.org/10.1126/science.1244693, 2013.

Harris, N. L., Brown, S., Hagen, S. C., Saatchi, S. S., Petrova, S., Salas, W., Hansen, M. C., Potapov, P. V and Lotsch, A.: Baseline map of carbon emissions from deforestation in tropical regions., Science, 336, 1573-1576, https://doi.org/10.1126/science.1217962, 2012.

Hartley, A. J., MacBean, N., Georgievski, G., and Bontemps, S.: Uncertainty in plant functional type distributions and its impact 
on land surface models, Remote Sens. Environ., 203, 71-89, https://doi.org/10.1016/j.rse.2017.07.037, 2017.

Heinimann, A., Mertz, O., Frolking, S., Egelund Christensen, A., Hurni, K., Sedano, F., Parsons Chini, L., Sahajpal, R., Hansen, M., and Hurtt, G.: A global view of shifting cultivation: Recent, current, and future extent, edited by B. Poulter, Plos One, 12, e0184479, https://doi.org/10.1371/journal.pone.0184479, 2017.

Houghton, R. A.: The annual net flux of carbon to the atmosphere from changes in land use 1850-1990, Tellus B, 51, 298-313, https://doi.org/10.1034/j.1600-0889.1999.00013.x, 1999.

Houghton, R. A. and Nassikas, A. A.: Global and regional fluxes of carbon from land use and land cover change 1850-2015, Global Biogeochem. Cy., 31, 456-472, https://doi.org/10.1002/2016GB005546, 2017.

Hurtt, G. C., Chini, L. P., Frolking, S., Betts, R. A., Feddema, J., Fischer, G., Fisk, J. P., Hibbard, K., Houghton, R. A., Janetos, A., Jones, C. D., Kindermann, G., Kinoshita, T., Klein Goldewijk, K., Riahi, K., Shevliakova, E., Smith, S., Stehfest, E., Thomson, A., Thornton, P., van Vuuren, D. P., and Wang, Y. P.: Harmonization of land-use scenarios for the period 1500-2100: 600 years of global gridded annual land-use transitions, wood harvest, and resulting secondary lands, Climatic Change, 109, 117-161, https://doi.org/10.1007/s10584-011-0153-2, 2011.

Hurtt, G. C., Frolking, S., Fearon, M. G., Moore, B., Shevliakova, E., Malyshev, S., Pacala, S. W., and Houghton, R. A.: The underpinnings of land-use history: three centuries of global gridded land-use transitions, wood-harvest activity, and resulting secondary lands, Glob. Change Biol., 12, 1208-1229, https://doi.org/10.1111/j.1365-2486.2006.01150.x, 2006.

Keenan, R. J., Reams, G. A., Achard, F., de Freitas, J. V., Grainger, A., and Lindquist, E.: Dynamics of global forest area: results from the FAO Global Forest Resources Assessment 2015, Forest Ecol. Manag., 352, 9-20, https://doi.org/10.1016/j.foreco.2015.06.014, 2015.

Klein Goldewijk, K., Beusen, A., Doelman, J., and Stehfest, E.: Anthropogenic land use estimates for the Holocene - HYDE 3.2, Earth Syst. Sci. Data, 9, 927-953, https://doi.org/10.5194/essd9-927-2017, 2017.

Koh, L. P., Miettinen, J., Liew, S. C., and Ghazoul, J.: Remotely sensed evidence of tropical peatland conversion to oil palm, P. Natl. Acad. Sci. USA, 108, 5127-5132, https://doi.org/10.1073/pnas.1018776108, 2011.

Le Quéré, C., Andrew, R. M., Canadell, J. G., Sitch, S., Korsbakken, J. I., Peters, G. P., Manning, A. C., Boden, T. A., Tans, P. P., Houghton, R. A., Keeling, R. F., Alin, S., Andrews, O. D., Anthoni, P., Barbero, L., Bopp, L., Chevallier, F., Chini, L. P., Ciais, P., Currie, K., Delire, C., Doney, S. C., Friedlingstein, P., Gkritzalis, T., Harris, I., Hauck, J., Haverd, V., Hoppema, M., Klein Goldewijk, K., Jain, A. K., Kato, E., Körtzinger, A., Landschützer, P., Lefèvre, N., Lenton, A., Lienert, S., Lombardozzi, D., Melton, J. R., Metzl, N., Millero, F., Monteiro, P. M. S., Munro, D. R., Nabel, J. E. M. S., Nakaoka, S.-I., O’Brien, K., Olsen, A., Omar, A. M., Ono, T., Pierrot, D., Poulter, B., Rödenbeck, C., Salisbury, J., Schuster, U., Schwinger, J., Séférian, R., Skjelvan, I., Stocker, B. D., Sutton, A. J., Takahashi, T., Tian, H., Tilbrook, B., van der Laan-Luijkx, I. T., van der Werf, G. R., Viovy, N., Walker, A. P., Wiltshire, A. J., and Zaehle, S.:
Global Carbon Budget 2016, Earth Syst. Sci. Data, 8, 605-649, https://doi.org/10.5194/essd-8-605-2016, 2016.

Li, W., Ciais, P., MacBean, N., Peng, S., Defourny, P., and Bontemps, S.: Major forest changes and land cover transitions based on plant functional types derived from the ESA CCI Land Cover product, Int. J. Appl. Earth Obs., 47, 30-39, https://doi.org/10.1016/j.jag.2015.12.006, 2016.

Li, W., MacBean, N., Ciais, P., Defourny, P., Lamarche, C., Bontemps, S., Houghton, R., and Peng, S.: Derivation of plant functional type (PFT) maps from the ESA CCI Land Cover product, version 1, Zenodo, https://doi.org/10.5281/zenodo.834229, 2017a.

Li, W., MacBean, N., Ciais, P., Defourny, P., Lamarche, C., Bontemps, S., Houghton, R., and Peng, S.: Derivation of plant functional type (PFT) maps from the ESA CCI Land Cover product, version 2, Zenodo, https://doi.org/10.5281/zenodo.1048163, 2017b.

NBSC: National data from National Bureau of Statistics of China, available at: http://data.stats.gov.cn/easyquery.htm?cn=C01, last access: 16 September 2015, 2015.

Nickerson, C., Ebel, R., Borchers, A., and Carriazo, F.: Major uses of land in the United States, 2007, US Department of Agriculture, Economic Research Service, USA, 2011.

Olofsson, P., Foody, G. M., Herold, M., Stehman, S. V., Woodcock, C. E., and Wulder, M. A.: Good practices for estimating area and assessing accuracy of land change, Remote Sens. Environ., 148, 42-57, https://doi.org/10.1016/j.rse.2014.02.015, 2014.

Peng, S.-S., Piao, S., Zeng, Z., Ciais, P., Zhou, L., Li, L. Z. X., Myneni, R. B., Yin, Y., and Zeng, H.: Afforestation in China cools local land surface temperature., P. Natl. Acad. Sci. USA, 111, 2915-2919, https://doi.org/10.1073/pnas.1315126111, 2014.

Pérez-Hoyos, A., Rembold, F., Kerdiles, H., and Gallego, J.: Comparison of global land cover datasets for cropland monitoring, Remote Sens., 9, 1118, https://doi.org/10.3390/rs9111118, 2017.

Poulter, B., MacBean, N., Hartley, A., Khlystova, I., Arino, O., Betts, R., Bontemps, S., Boettcher, M., Brockmann, C., Defourny, P., Hagemann, S., Herold, M., Kirches, G., Lamarche, C., Lederer, D., Ottlé, C., Peters, M., and Peylin, P.: Plant functional type classification for earth system models: results from the European Space Agency's Land Cover Climate Change Initiative, Geosci. Model Dev., 8, 2315-2328, https://doi.org/10.5194/gmd8-2315-2015, 2015.

Sannier, C., McRoberts, R. E., and Fichet, L.-V.: Suitability of Global Forest Change data to report forest cover estimates at national level in Gabon, Remote Sens. Environ., 173, 326-338, https://doi.org/10.1016/j.rse.2015.10.032, 2016.

Shevliakova, E., Pacala, S. W., Malyshev, S., Hurtt, G. C., Milly, P. C. D., Caspersen, J. P., Sentman, L. T., Fisk, J. P., Wirth, C., and Crevoisier, C.: Carbon cycling under 300 years of land use change: importance of the secondary vegetation sink, Global Biogeochem. Cy., 23, GB2022, https://doi.org/10.1029/2007GB003176, 2009.

Stocker, B. D., Feissli, F., Strassmann, K. M., Spahni, R., and Joos, F.: Past and future carbon fluxes from land use change, shifting cultivation and wood harvest, Tellus B, 66, 23188, https://doi.org/10.3402/tellusb.v66.23188, 2014.

Tropek, R., Sedláček, O., Beck, J., Keil, P., Musilová, Z., Símová, I., and Storch, D.: Comment on "High-resolution global 
maps of 21st-century forest cover change", Science, 344, 981, https://doi.org/10.1126/science.1248753, 2014.

Tsendbazar, N.-E., de Bruin, S., Fritz, S., and Herold, M.: Spatial accuracy assessment and integration of global land cover datasets, Remote Sens., 7, 15804-15821, https://doi.org/10.3390/rs71215804, 2015.

Waldner, F., Fritz, S., Di Gregorio, A., Plotnikov, D., Bartalev, S., Kussul, N., Gong, P., Thenkabail, P., Hazeu, G., Klein, I., Löw, F., Miettinen, J., Dadhwal, V., Lamarche, C., Bontemps, S., and Defourny, P.: A unified cropland layer at $250 \mathrm{~m}$ for global agriculture monitoring, Data, 1, 3, https://doi.org/10.3390/data1010003, 2016.

Wilkenskjeld, S., Kloster, S., Pongratz, J., Raddatz, T., and Reick, C. H.: Comparing the influence of net and gross anthropogenic land-use and land-cover changes on the carbon cycle in the MPI-ESM, Biogeosciences, 11, 4817-4828, https://doi.org/10.5194/bg-11-4817-2014, 2014.
Yang, Y., Xiao, P., Feng, X., and Li, H.: Accuracy assessment of seven global land cover datasets over China, ISPRS J. Photogramm. Remote Sens., 125, 156-173, https://doi.org/10.1016/j.isprsjprs.2017.01.016, 2017.

Yue, C., Ciais, P., Luyssaert, S., Li, W., McGrath, M. J., Chang, J., and Peng, S.: Representing anthropogenic gross land use change, wood harvest and forest age dynamics in a global vegetation model ORCHIDEE-MICT (r4259), Geosci. Model Dev. Discuss., https://doi.org/10.5194/gmd-2017-118, in review, 2017.

Zhao, K. and Jackson, R. B.: Biophysical forcings of land-use changes from potential forestry activities in North America, Ecol. Monogr., 84, 329-353, https://doi.org/10.1890/12-1705.1, 2014. 